\title{
ENHANCED BIOREMEDIATION OF DIESEL OIL CONTAMINATED SOIL AND WASTEWATERS BY HYDROCARBONS- DEGRADING BACTERIA
}

\author{
B. Kolwzan, \\ K. Piekarska, J. Kiernicka, E. Sliwka \\ Wroclaw University of Technology, Poland
}

\begin{abstract}
Strains of microorganisms actively degrading diesel oil were used as inoculants in the process of biological treatment of contaminated soils and wastewaters. The study showed that bioremediation was faster in inoculated lysimeters compared to control lysimeters. On the other hand inoculation of activated sludge with active microorganisms increased the efficiency of bioremediation of oil containing wastewaters of about $19.2 \%$. The bioindication study showed that no harmful metabolites were produced during the biodegradation process.
\end{abstract}

\section{INTRODUCTION}

The pollution of the environment with petroleum products is particularly dangerous because of their toxic, and sometimes mutagenic and carcinogenic effects on living organisms. Although the indigenous microflora is able to use these compounds as food substrates, the natural biodegradation process is very slow and it may take many years in case of heavy pollution. Therefore the biodegradation process should be accelerated by a man intervention. This consists in the use of highly active strains of microorganisms as inoculants in the processes of biological treatment of soil and wastewaters contaminated with oil.

The aim of this work was to evaluate the possibility of enhancement of the natural bioremediation process by inoculating soil and activated sludge with strains actively degrading oil.

\section{MATERIALS AND METHODS}

Microorganisms able to degrade diesel oil components were isolated from soil and wastewater samples collected in the vicinity of filling stations in the city of Wroclaw (Poland). The strains were identified on the basis of their morphological, physiological and biochemical features according to Bergey's identification manual [1].

The study on influence of active bacterial strains on the efficiency of bioremediation of soil contaminated with oil was carried out in field lysimeters situated on the premises of Agro- and Hydrometeorology Observatory of the Academy of Agriculture in Wroclaw. The initial oil concentration in soil was of about $9.5 \%$ dry matter. The soil moisture was hold on the level of $12-15 \%$. Ammonium nitrate, ammonium phosphate and potassium phosphate were added to the soil in two weeks intervals in order to provide the proper ratio of nitrogen 
and phosphorus to the carbon contained in soil $[\mathrm{C}: \mathrm{N}: \mathrm{P}=10: 1: 0.1]$. In the course of the experiment, the quantitative estimation of diesel oil removal from soil was performed by means of gas chromatography.

The study on influence of active bacterial strains on the efficiency of bioremediation of oil polluted wastewaters was carried out by activated sludge method. The activated sludge was cultivated in the system proposed by Gomolka [2] in two variants. The first chamber was filled up with $5000 \mathrm{mg}$ of dry matter (d.m.)/ $/ \mathrm{dm}^{3}$ of activated sludge. The second chamber contained at the beginning of the experiment approximately $4500 \mathrm{mg} \mathrm{d.m} . / \mathrm{dm}^{3}$ of activated

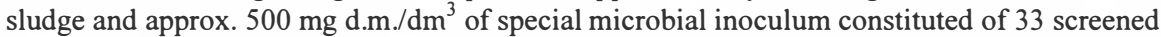
strains. The study was carried out in room temperature for 42 days.

All chambers were supplied with synthetic wastewaters at the rate of $2 \mathrm{dm}^{3} / 24 \mathrm{~h}$ and with diesel oil at concentration of $200 \mathrm{mg} / \mathrm{dm}^{3}$ first, and at concentration of $400 \mathrm{mg} / \mathrm{dm}^{3}$, since the $22 \mathrm{nd}$ day of the experiment. Every 7 days the $2 \mathrm{nd}$ chamber was seeded with $500 \mathrm{mg}$ d.m. $/ \mathrm{dm}^{3}$ of bacterial inoculum [3].

The activated sludge performance was evaluated based on the following parameters: microscopic and macroscopic visual analyses of the sludge, number of free-swimming bacteria in the effluent, number of diesel oil-degrading bacteria in the activated sludge, dehydrogenase activity of the activated sludge, volume index of activated sludge, BOD, COD, determination of diesel oil concentration by ether-extract method and by gas chromatography [4].

At the end of both of the studied bioremediation processes, biological properties of soil and wastewaters were evaluated on the basis of Ames test, after a proper extraction of samples [5].

This test, the Ames assay, measures mutations induced by chemicals, either directly or after metabolism by tissue enzymes, in Salmonella typhimurium LT2. The bacteria then are grown on a special medium lacking of histidine that allows only those with a certain mutation to multiply. The number of revertants to prototrophies is a measure of the biological activity of the chemical. In addition, the mutagenicity and toxicity of chemicals, as a function of specific DNA repair enzymes, is also assayed in this facility.

\section{RESULTS}

\section{Bioremediation of soil using active bacterial strains.}

The study was carried out in 12 field lysimeters. The surface layer of soil in each lysimeter, to the depth of $15 \mathrm{~cm}$, weighting $30 \mathrm{~kg}$, was contaminated with diesel oil. The oil was filled up to the final concentration in soil of $9.5 \%$ dry matter. The oil was applied in two batches, at the first day of the experiment and after 14 days, in order to allow the gradual adaptation of the indigenous microflora.

The 12 lysimeters were divided in three parts. One part of lysimeters (H29) were inoculated with the strain Acinetobacter and another one (B3) with Pseudomonas. The remaining lysimeters $(\mathrm{KO})$ were not inoculated and served as controls [KO] where bioremediation was carried out by the indigenous soil microflora.

The diesel oil used in this experiment was a complex mixture of several compounds, mainly of different homologous of hydrocarbons. Only a few compounds were in quantity not exceeding $0.5-1 \%$ of mass. The compounds present in the diesel oil and the biodegradation products were identified by GC-MS. Based on the recorded TIC chromatograms of selected fragmentation ions (85 - n-alkanes, 183 - isoprenoids, 82 - alkylcyclohexanes, 91 alkylbenzenes), molecular ions (128 - naphthalene, 142 methyl-naphthalenes) and mass spectra of different compounds, it was found that hydrocarbons containing 10-26 carbon 
atoms in the molecules, especially n-alkanes $\mathrm{C}_{10}-\mathrm{C}_{20}$ and isoprenoids: norpristane, pristane, phytane were present in the diesel oil (Fig.1.). In the group of naphtenes hydrocarbons, alkyl derivatives of cyclohexane with $\mathrm{C}_{3}-\mathrm{C}_{15}$ substituents, and in the group of aromatic hydrocarbons alkyl derivatives of benzene, as well as naphtalene and methyl-naphthalenes were identified (Fig.1.).

The oil removal from soil was the highest three weeks after inoculation of soil with bacteria. It was the result of microbial activity, but also of volatilisation of part of hydrocarbons and of their chemical oxidation. The next stage of the diesel oil degradation was much slower. Nevertheless, the difference between the rate of biodegradation in inoculated lysimeters and control ones was significant. This difference decreased in the course of the experiment.

Gas chromatography showed that n-alkanes were degraded in the first weeks of the study. On the other hand, the aromatic hydrocarbons degradation was very slow as well in inoculated lysimeters as in control ones (Fig.2). After 17 weeks of the experiment the hydrocarbon content in soil was similar for all lysimeters. It was observed that inoculation of soil only accelerated the bioremediation process, but it did not increase its efficiency. Therefore it was recognised necessary to repeat the inoculation of soil contained in the lysimeters. The strain Arthrobacter from the collection of the Biology and Ecology Laboratory of the Technical University of Wroclaw was used for this inoculation. The characteristic of this Arthrobacter strain is its high ability to degrade aromatic hydrocarbons. This inoculation revealed itself to be successful, as further reduction of diesel oil content in soil was achieved. It reached $409 \mathrm{mg} / \mathrm{kg}$ in control lysimeters and $114 \mathrm{mg} / \mathrm{kg}$ and $31 \mathrm{mg} / \mathrm{kg}$ in the inoculated lysimeters $\mathrm{H} 29$ and B3, respectively (Table 1).

Table 1. Concentration of diesel oil in soil during the bioremediation process $[\mathrm{mg} / \mathrm{kg} \mathrm{d} . \mathrm{m}$. of soil

\begin{tabular}{|l|l|l|l|}
\hline $\begin{array}{l}\text { Time } \\
\text { [weeks] }\end{array}$ & \multicolumn{4}{|c|}{ Tested lysimeter } \\
\hline & B3 & H29 & KO \\
\hline 1 & 85440 & 85440 & 85440 \\
\hline 3 & 28560 & 31200 & 58670 \\
\hline 6 & 21700 & 26200 & 32240 \\
\hline 9 & 12450 & 18670 & 28980 \\
\hline 12 & 10890 & 12450 & 14400 \\
\hline 17 & 1002 & 1405 & 1581 \\
\hline 22 & 31 & 114 & 409 \\
\hline
\end{tabular}

Bioindication tests performed with the Ames method were an important part of the study. As well soil samples as samples of lysimeters effluents were tested (Table 2). The Ames test gave negative results for the major part of samples. Any potentially mutagenic and carcinogenic substances haven't been found, except for the control lysimeters where the diesel oil biodegradation was carried out only by the soil natural microflora. 
Table 2. Results of Ames test for the lysimeter KO.

\begin{tabular}{|c|c|c|c|c|}
\hline $\begin{array}{c}\text { Time } \\
\text { [weeks] }\end{array}$ & \multicolumn{2}{|c|}{ TAa98 } & \multicolumn{2}{c|}{ TAa100 } \\
\hline & $+\mathrm{S} 9$ & $-\mathrm{S} 9$ & $+\mathrm{S} 9$ & $-\mathrm{S} 9$ \\
\hline 3 & $29,3 \pm 2,0$ & $21,2 \pm 1,2$ & $143,6 \pm 4,1$ & $140,3 \pm 7,2$ \\
\hline 9 & $35,1 \pm 1,3$ & $24,4 \pm 2,4$ & $153, \mathrm{~d} \pm 5,1$ & $142,5 \pm 6,9$ \\
\hline 12 & $32,5 \pm 1,1$ & $22,5 \pm 2,8$ & $165,2 \pm 3,9$ & $151,4 \pm 5,1$ \\
\hline 17 & $30,1 \pm 0,9$ & $* 56,4 \pm 3,1$ & $173,5 \pm 4,3$ & $158,6 \pm 6,3$ \\
\hline 22 & $27,2 \pm 1,6$ & $23,6 \pm 1,4$ & $152,5 \pm 4,3$ & $150,1 \pm 3,8$ \\
\hline r.sp** & $29,5 \pm 1,5$ & $23,6 \pm 2,3$ & $161,2 \pm 4,3$ & $141,3 \pm 5,5$ \\
\hline
\end{tabular}

*the number of revertants twice higher than the spontaneous reversion signifies that the compounds contained in the soil sample have mutagenic and carcinogenic properties

** spontaneous reversion

Some dangerous metabolites were found to be present in samples collected 17 weeks after the beginning of the experiment. In the next part of samples collected after 22 weeks, this kind of substances haven't been found. The natural soil microflora showed to be able to degrade and detoxicate these compounds. Nevertheless, because of the real possibility of production of compounds threatening biological life during bioremediation, this process should be carried out by the ex situ method. This only could guarantee the total security for both soil and water environment. The study showed that application of active bacterial strains is very useful for stimulation of the treatment of soil contaminated with petroleum products. It was observed that the process was highly accelerated and more safe because no mutagenic or carcinogenic metabolites were produced.

\section{Bioremediation of diesel oil containing wastewaters using active bacterial strains.}

Sludges from both chambers: the first, control one and the second, inoculated during dosage of oil containing wastewaters, changed in a similar way. Their colour changed into darker. They had characteristic oil smell. Settling properties were satisfactory. Activated sludge flocks became more compact due to the adsorption of oil droplets on flocks surface during the diesel oil dosage into the chambers. Quantitative and qualitative changes of species composition of the activated sludges were also observed, it especially concerned the particularly diesel oil sensitive population of ciliates. Finally, biocenoses composed of bacteria and rotifers were observed in all chambers.

Every 7 days bacterial inoculum was added to the second chamber, therefore the number of bacteria was determined in both effluents. The highest number of free-swimming bacteria was observed in the effluent from the $2^{\text {nd }}$, inoculated, chamber. However this number decreased with time. High variations of bacteria number due to the inoculation were also observed in this chamber. The number of free-swimming bacteria in the effluents from the first chamber remained rather steady. The total number of bacteria in the effluents ranged 
from 102 to 920 per $1 \mathrm{~cm}^{3}$ and from 950 to 3500 per $1 \mathrm{~cm}^{3}$ for the first and the second chamber, respectively.

The titer of diesel oil degrading bacteria was fairly constant for all tested sludges in course of the experiment. For the inoculated sludge, it was on the level of $10^{-9}$ and for the control one, on the level of $10^{-3}$ to $10^{-5}$.

The initial sludge volume index was stabilised at $56 \mathrm{~cm}^{3} / \mathrm{g}$. This corresponded to the sludges volume of $280 \mathrm{~cm}^{3} / \mathrm{dm}^{3}$ and the dry matter of $5.0 \mathrm{~g} / \mathrm{dm}^{3}$.

In the $1 \mathrm{st}$ chamber, the activated sludge dry matter ranged from 4.1 to $5.4 \mathrm{~g} / \mathrm{dm}^{3}$, sludge volume was between 280 and $410 \mathrm{~cm}^{3} / \mathrm{dm}^{3}$ and sludge volume index ranged from 56.0 to $91.1 \mathrm{~cm}^{3} / \mathrm{g}$. In the $2 \mathrm{nd}$ chamber, the values of the respective parameters were: $4 . \mathbf{d} 8-5.46$ $\mathrm{g} / \mathrm{dm}^{3}, 270-450 \mathrm{~cm}^{3} / \mathrm{dm}^{3}$ and $54.9-82.4 \mathrm{~cm}^{3} / \mathrm{g}$.

Effluents from aeration chambers had alkaline reaction in the range of $7.3-8.1$.

Oxygen concentration in both chambers varied from 2.8 to $3.2 \mathrm{mg} \mathrm{O}_{2} / \mathrm{dm}^{3}$.

Results of diesel oil degradation study are summarised in table 3. Diesel oil concentrations determined by the ether extract assay and by the quantitative gas chromatography analyses are presented. Results of TOC , BOD and COD measurements in raw wastewaters and effluents are also given in this table.

These results clearly indicate a very high removal of hydrocarbons by both of tested activated sludges. The degree of diesel oil removal, calculated on the basis of all abovementioned methods, was greater for the activated sludge inoculated with active bacterial strains. Inoculation of the activated sludge increased the wastewater treatment efficiency of $16.3 \%$ for measurements performed with the ether extract assay, of $13.8 \%$ for gas chromatography analyses, of $3.6 \%$ for TOC, $27,7 \%$ for BOD and $34,6 \%$ for COD measurements, compared to the non-inoculated sludge. A correlation between the degree of diesel oil removal and the diesel oil concentration in the synthetic wastewaters was observed in this study. The increase of diesel oil concentration $\left(22^{\text {nd }}\right.$ day of the experiment $)$ caused a temporary decrease of the wastewaters treatment efficiency especially in the $1^{\text {st }}$ chamber.

The high degree of diesel oil biodegradation by the inoculated sludge was confirmed by the results of dehydrogenase activity measurements.

The inoculated sludge showed a high level of enzymatic activity already at the beginning of the experiment. In course of the hydrocarbons biodegradation process, the dehydrogenase activity was growing. A small decrease was observed after 21 days and then the enzymatic activity started to grow again. It was associated with a higher concentration of diesel oil in the wastewaters. On the other hand, the sludge from the $1^{\text {st }}$ chamber showed a lower enzymatic activity since the beginning of the experiment. In the first period of the experiment, the dehydrogenase activity was decreasing. After 8-11 days, an increase of this activity was observed. And it remained at a fairly constant level until the end of the experiment, except for the time when a higher fuel oil concentration was dosed into the chamber.

The Ames test performed on effluents from different days of the process gave negative results. It means that metabolites produced during biological oxygenation of diesel oil components had no mutagenic and carcinogenic properties. 
ECOLOGICAL TECHNOLOGY AND MANAGEMENT

KALMAR, SWEDEN, September 22-24, 1999

Table 3. Comparison of removal of diesel oil by activated sludge (O.I.) and by sludge inoculated with active strains of microorganisms (O.II).

\begin{tabular}{|c|c|c|c|c|c|c|c|c|c|c|c|c|c|c|c|}
\hline \multirow[t]{3}{*}{ Days } & \multicolumn{15}{|c|}{ Degree of diesel oil removal (in \%) based on: } \\
\hline & \multicolumn{3}{|c|}{ Ether extract } & \multicolumn{3}{|c|}{ Gas chromatography } & \multicolumn{3}{|l|}{ TOC } & \multicolumn{3}{|l|}{ BOD } & \multicolumn{3}{|l|}{ COD } \\
\hline & O.I. & O.II. & $\begin{array}{l}\text { Differenc } \\
\text { e }\end{array}$ & O.I. & O.II. & $\begin{array}{l}\text { Differen } \\
\text { ce }\end{array}$ & O.I. & O.II. & $\begin{array}{l}\text { Differen } \\
\text { ce }\end{array}$ & O.I. & O.II. & $\begin{array}{l}\text { Differen } \\
\text { ce }\end{array}$ & O.I. & O.II. & $\begin{array}{l}\text { Differen } \\
\text { ce }\end{array}$ \\
\hline 1 & 82,4 & 93,2 & 10,8 & - & - & - & - & - & - & 56,1 & 75,6 & 19,5 & 39,0 & 61,5 & 22,5 \\
\hline 3 & 80,7 & 90,7 & 10,0 & 86,2 & 99,3 & 13,1 & 93,3 & 94,9 & 1,6 & 52,0 & 78,0 & 26,0 & 36,1 & 70,2 & 34,1 \\
\hline 5 & 79,2 & 92,1 & 12,9 & - & - & - & - & - & - & 49,6 & 74,8 & 25,2 & 32,7 & 60,0 & 27,3 \\
\hline 8 & 80,4 & 94,2 & 13,8 & 85,6 & 97,9 & 12,3 & 87,4 & 90,4 & 3,0 & 45,5 & 77,2 & 31,7 & 30,7 & 61,5 & 30,8 \\
\hline 11 & 83,7 & 90,8 & 7,1 & - & - & - & - & - & - & 44,7 & 78,0 & 33,3 & 28,3 & 63,4 & 34,1 \\
\hline 14 & 77,2 & 97,1 & $\mid 19,9$ & 87,8 & 95,4 & 7,6 & 90,1 & 91,3 & 1,2 & 45,5 & 79,7 & 34,2 & 28,3 & 62,9 & 34,6 \\
\hline 16 & 79,1 & 90,2 & 11,1 & - & - & - & - & - & - & 47,2 & 78,9 & 31,7 & 29,3 & 63,8 & 34,6 \\
\hline 19 & 77,2 & 95,6 & 18,4 & 85,4 & 92,1 & 6,7 & 90,3 & 95,7 & 5,4 & 48,8 & 79,7 & 30,9 & 30,2 & 64,9 & 34,7 \\
\hline 22 & 71,4 & 85,4 & 14,0 & - & - & - & - & - & - & 59,1 & 80,1 & 21,0 & 32,4 & 62,8 & 30,4 \\
\hline 25 & 65,4 & 85,7 & 20,3 & 71,2 & 90,4 & 19,2 & 87,3 & 94,1 & 6,8 & 48,0 & 78,0 & 30,0 & 29,0 & 64,2 & 35,2 \\
\hline 28 & 65,0 & 89,0 & 24,0 & - & - & - & - & - & - & 46,6 & 85,8 & 39,2 & 30,0 & 65,2 & 35,2 \\
\hline 31 & 69,4 & 95,2 & 25,8 & 69,5 & 91,2 & 21,7 & 85,2 & 92,1 & 6,9 & 54,0 & 84,7 & 30,7 & 33,4 & 72,6 & 39,2 \\
\hline 35 & 77,1 & 93,1 & 16,0 & - & - & - & - & - & - & 60,8 & 85,2 & 24,4 & 35,2 & 74,1 & 39,5 \\
\hline 38 & 75,2 & 92,7 & 17,5 & 73,4 & 89,7 & 16,3 & 90,3 & 90,4 & 0,1 & 61,4 & 85,8 & 24,4 & 34,8 & 74,7 & 39,9 \\
\hline
\end{tabular}


ECOLOGICAL TECHNOLOGY AND MANAGEMENT KALMAR, SWEDEN, September 22-24, 1999

\begin{tabular}{|l|l|l|l|l|l|l|l|l|l|l|l|l|l|l|l|}
\hline $\mathbf{4 0}$ & 77,3 & 94,2 & 16,9 & - & - & - & - & - & - & 62,5 & 85,2 & 22,7 & 34,1 & 74,1 & 40,0 \\
\hline $\mathbf{4 2}$ & 74,1 & 96,1 & 22,0 & - & - & - & - & - & - & 62,5 & 84,7 & 22,2 & 32,8 & 75,1 & 42,3 \\
\hline $\begin{array}{l}\text { Averag } \\
\text { e }\end{array}$ & $\mathbf{7 5 , 9}$ & $\mathbf{9 2 , 2}$ & $\mathbf{1 6 , 3}$ & $\mathbf{7 9 , 9}$ & $\mathbf{9 3 , 7}$ & $\mathbf{1 3 , 8}$ & $\mathbf{8 9 , 1}$ & $\mathbf{9 2 , 7}$ & $\mathbf{3 , 6}$ & $\mathbf{5 2 , 8}$ & $\mathbf{8 0 , 5}$ & $\mathbf{2 7 , 7}$ & $\mathbf{3 2 , 3}$ & $\mathbf{6 6 , 9}$ & $\mathbf{3 4 , 6}$ \\
\hline
\end{tabular}




\section{CONCLUSIONS}

1.The study showed that bioremediation process of diesel oil in soil was faster in lysimeters inoculated with Acinetobacter and Pseudomonas strains compared to control lysimeters.

2. The activated sludge inoculated with strains of bacteria actively degrading diesel oil compounds, degraded the oil with an average efficiency of $82.1 \%$. This efficiency was higher of about $19,2 \%$ compared to the degrading efficiency of the non-inoculated sludge.

3. Mutagenic and carcinogenic substances were not found to be produced during the bioremediation process neither in the inoculated soil nor in the effluents from wastewaters treatment.

\section{REFERENCES}

1. Piekarska K., Moskal J. M., Jadczyk P. and Marszałek M. (1995). Izolacja i diagnostyka aktywnych bakterii rozkladajacych produkty ropopochodne. Instytut Inzynierii Ochrony Srodowiska Politechniki Wroclawskiej, Raport serii SPR 52/95, Wroclaw, Poland.

2. Gomolka E. and Bialy E. (1971). Urzadzenie do laboratoryjnych badan osadu czynnego. Gaz, Woda i Technika Sanitarna, nr 1, tom XLV.

3. Piekarska K. and Pawlak J. (1994). Ocena skutecznosci osadu czynnego w oczyszczaniu sciekow zaolejonych. Ochrona Srodowiska 1(52).

4. Hermanowicz W. et al. (1976). Fizyczno-chemiczne badanie wody i sciekow. Arkady, Warszawa.

5. Ames B. N., Mc Cann J. and Yamashi E. (1994). Methods for detecting carcinoges and mutagens with Salmonella/mammalian-microsome mutagenicity test. Mutat. Res. 31, 347.364. DO1: https://doi.org/10.1016/0165-1161(75)90046-1 